\title{
Ascorbic Acid and Healing of Heat Injuries in the Guinea-pig Cornea
}

\author{
By F. W. CAMPBELL, I. D. FERGUSON AND R. C. GARRY \\ Institute of Physiology, University of Glasgow
}

(Received 29 October 1949)

It is accepted that the repair of connective tissue is defective in scurvy. Wounds of the cornea, however, may be superficial, involving only the epithelium, or they may be deep and invade the collagenous substantia propria. Moreover, the power of proliferation of the epidermis is not impaired in scurvy (Wolbach \& Howe, 1926); in keeping with this finding, Galloway, Garry \& Hitchin (1948-9) found that cye wounds, produced mechanically and confined to the corneal epithelium, healed with undiminished speed in guinea-pigs maintained on a deficient intake of ascorbic acid. The epithelium covering the cornea is said to heal by proliferation and migration of epithelial cells, so that no new formation of collagen is required (Arey \& Covode, 1943; Buschke, Friedenwald \& Fleischmann, 1943; Mann, 1944). The present investigation was designed to study and compare the rate of healing of both superficial and deep corneal wounds in normal and in subscorbutic guinea-pigs.

Another factor may be of importance; ascorbic acid is known not to be uniformly distributed throughout the body, and it seems to have a very selective distribution within the cornea itself, although its exact location is by no means settled. Schmid \& Bürki (1943), using a histochemical method, found the greatest concentration in the superficial epithelial layers of the cornea. The substantia propria had a lower content, although there was a high concentration in the region of Bowman's and Descemet's membranes.

Henkes (1946), on the other hand, who extracted and titrated ascorbic acid from various regions of the cornea, found no ascorbic acid in Bowman's membrane, a little in the corneal epithelium and a high concentration in the substantia propria and in Descemet's membrane. The subepithelial portion of the substantia propria contained the highest concentration of vitamin C. Of importance for our work was the fact that, in experimental scurvy in guinea-pigs, the ascorbic acid disappeared from the cornea in from 2 to 3 weeks, although the glutathione content remained unchanged. Pirie (1946), using microtitration, found the concentration of ascorbic acid to be greatest in the corneal epithelium.

Such findings made it essential that all our experimental guinea-pigs should start with a uniform high content of ascorbic acid. Half the animals had then to receive a diet calculated to produce a subscorbutic state over a period of time necessary to allow the ascorbic acid to disappear from the tissues of the cornea. To maintain complete saturation of the tissues of a guinea-pig with ascorbic acid Kellie \& Zilva (I939) believe that $20 \mathrm{mg}$. by mouth daily is necessary. However, as small a dose as $2 \mathrm{mg}$. daily 
will prevent microscopic and macroscopic signs of scurvy. Kuether, Telford \& Roe (1944) believe that 21 days are required to bring a guinea-pig to a steady state of saturation with ascorbic acid.

We had also to try to design an apparatus to test the strength of the cornea after injury, since incised wounds in scorbutic guinea-pigs are structurally weak after apparent healing (Jones, Bartlett, Ryan \& Drummey, 1943), and Bourne (1944) claims that there is a direct relationship between the tensile strength of scar tissue and the content of ascorbic acid in healing, incised skin wounds.

\section{EXPERIMENTAL}

\section{Animals}

Female non-pregnant guinea-pigs were used, with initial weights between $45^{\circ}$ and $650 \mathrm{~g}$. The animals were weighed every and day. The guinea-pigs were kept in groups of five or six in wire and metal cages $24 \times 18 \times 12$ in. Cages were sterilized twice weekly. The animals were kept and examined in one room with a temperature between 65 and $75^{\circ} \mathrm{F}$.

\section{Diets}

Basal diet. The basal diet was crushed rat-cake cubes (Thomson, 1936) well moistened with water. These cubes are free from ascorbic acid. To supplement the diet six drops of cod-liver oil (minimum content 500 i.u. vitamin $A$ and 50 i.u. vitamin $\mathrm{D} / \mathrm{g}$.) were added daily to the diet of each guinea-pig. The mash was placed in low-set troughs so that the animals had easy access to the food. Food and water were given without stint.

Ascorbic acid. In order to ensure that the guinea-pigs had a uniform initial level of saturation with ascorbic acid, $20 \mathrm{mg}$. ascorbic acid (Roche Products Ltd.) were given orally in $2 \mathrm{ml}$. water once a day. The solution was given to the animals by pipette within a few minutes of its preparation. This was given daily for $2 \mathrm{I}$ days to all guineapigs to obtain tissue equilibrium (Jones et al. 1943).

Controls. Control animals were injured after $2 \mathrm{I}$ days of saturation with vitamin $\mathrm{C}$, and the daily intake of $20 \mathrm{mg}$. was continued thereafter.

Deficient animals. After a preliminary 21 days of saturation with $20 \mathrm{mg}$. ascorbic acid, the animals were given $0.5 \mathrm{mg}$. ascorbic acid in $\mathrm{I}$ ml. water every 2 nd day for a further 21 days. Only then were injuries made to the cornea, the dosage of $0.5 \mathrm{mg}$. ascorbic acid every 2 nd day being continued thereafter.

\section{Apparatus}

Applicator. Small metal cylinders, having a flat end of I sq.mm. area, were heated among lead shot in a hot air oven to 120 or $180^{\circ}$. These applicators were used to produce superficial corneal burns.

Cautery. To produce deeper lesions a cautery was made from a loop of 32 s.w.g. platinum wire. A pre-determined constant voltage was fed to the cautery through a relay, type LF/FS (Londex, Ltd.), connected to the $r$ sec. contacts of an a.c. time 
clock (C. F. Palmer (London), Ltd.). This circuit allowed the current to flow through the cautery for exactly I sec.

Compression balance. The apparatus shown in Fig. $x$ was used to find the weight required to rupture the excised guinea-pig eye. 'This compression balance was used in two ways. First, by attaching a metal bar to the pivoted platform $C$ (Fig. $1, X$ ) it was possible to estimate the strength of a corneal lesion. Secondly, without the bar, the resistance of the sclera to compression could be found.

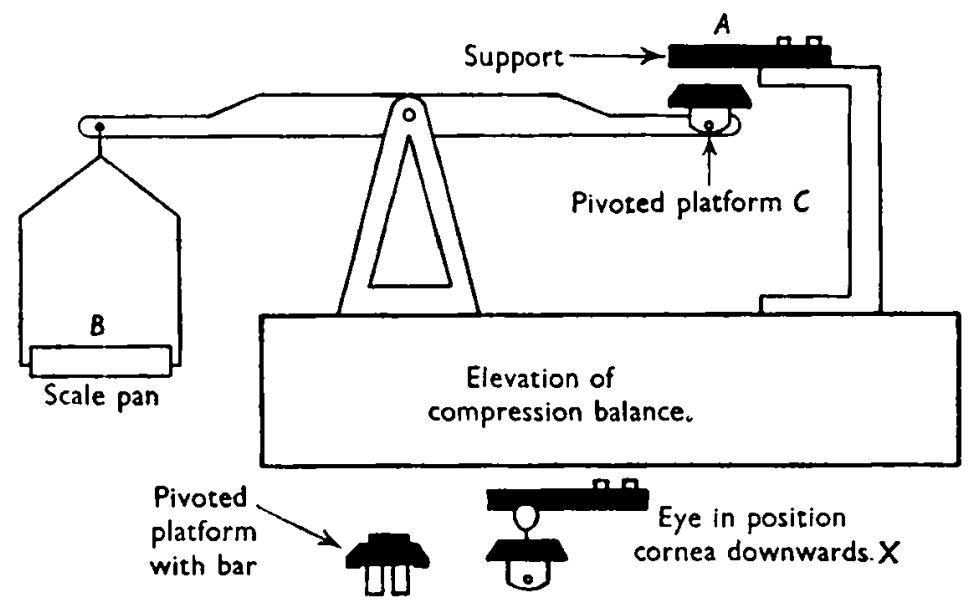

Fig. I. Compression balance for estimating strength of cornea and of sclera. $X$ shows position of bar and eye during estimations of corneal strength. The eye is compressed between a fixed support $A$ and a platform $C$. The force is applied by adding weights to the scale pan $B$. Both the support $A$ and platform $C$, pivoted on the end of the lever, are hollowed out to hold the excised eye.

\section{Technique}

Anaesthesia. The corneas were anaesthetized in all cases by instilling into the conjunctival sac two drops of a $2 \%$ amethocaine hydrochloride, B.P., solution. Anaesthesia was complete in $2 \mathrm{~min}$. and infliction of the injuries caused no discomfort since the corneal reflex was never elicited and the animals remained quiet. No signs of distress appeared after injury and in no case did infection occur.

Superficial corneal heat injuries. The applicator was removed with heat-insulated forceps from its bed of lead shot in the oven, and exactly 2 sec. later the sq.mm. surface was applied firmly to the cornea $2 \mathrm{~mm}$. from the corneo-sclerotic junction at ' 12 o'clock'. Contact was maintained for exactly $5 \mathrm{sec}$. Histological examinations showed that such injury affected only the epithelium over the cornea.

Deep corneal heat injuries. The cold cautery was pressed firmly and vertically on the cornea $2 \mathrm{~mm}$. from the corneo-sclerotic junction at ' 12 o'clock'. The current was allowed to flow for exactly i sec. and the cautery was removed I sec. later. 'This gave a standard heat injury similar to that used by. Campbell \& Michaelson (1949). Histological examination showed that the resulting lesion was $\mathrm{I} \mathrm{mm}$. in diameter, destroying the corneal epithelium and the anterior two-thirds of the substantia propria.

All thermal injuries were carried out by the same operator (F.W.C.) who was un- 
aware whether a control or a deficient animal was being injured. The injuries were inflicted alternately on the eyes of deficient and control animals.

Methods of examination. To assess the degree of healing, two drops of $2 \%$ aqueous sodium-fluorescein solution were instilled into the conjunctival sac and allowed to act for I min. exactly. Excess solution was removed first by mopping with filter-paper and then by instilling $6 \mathrm{ml}$. Ringer solution: the eye was examined immediately thereafter in darkness under a mercury vapour ultraviolet dark bulb lamp (General Electric Co. London, type M.B.W./V.) 8 in. from the injured eye. The intensity of fluorescence was compared with that of six dry strips of Whatman no. I filter-paper, $3 \times \mathrm{I}$ in., which had been impregnated with different known quantities of sodium fluorescein. Seven degrees of fluorescence intensity were recognized. Their value in terms of sodium fluorescein as $\mu \mathrm{g} . / \mathrm{sq} . \mathrm{cm}$. filter-paper, is shown in Table $\mathbf{r}$.

A fresh injury in all cases fluoresced brightly and appeared to have the degree of intensity of strip no. 6 . As healing progressed, the intensity fell off gradually and was evaluated against the other strips with smaller fluorescein content.

\section{Table I. Arbitrary standards used to estimate intensity of fluorescence}

Values given to intensity
of fluorescence
6
5
4
3
2
I
0

Sodium fluorescein
( $\mu \mathrm{g} . / \mathrm{sq} . \mathrm{cm}$. filter-paper)
$\mathbf{3 2}$
I6
8
4
2
I
No fluorescence

This subjective evaluation of the intensity of fluorescence from the damaged area of the cornea was very possibly influenced by the size of the lesion. But we clearly received the impression that the intensity of the fluorescence was affected by the stage of the healing process. However this may be, the intensity of fluorescence thus evaluated gave a reasonable assessment of the progress of healing.

In addition, the degrees of corneal oedema, of vascularization and of opacity were noted under intense focal illumination with the aid of a binocular loupe.

The complete examination was carried out on each animal by one observer (I.D.F.) at intervals of exactly $8 \mathrm{hr}$. day and night until fluorescence was absent at three consecutive examinations. 'Thereafter, each eye was examined at $24 \mathrm{hr}$. intervals.

\section{RESLLTS}

\section{General}

Control guinea-pigs were healthy and gained weight continuously before and after operation.

The deficient animals showed a gain in weight during the initial period of saturation. This gain in weight continued for 10 days on the decreased intake of $0.5 \mathrm{mg}$. ascorbic 
acid every 2nd day. Thereafter, they began to lose weight (Fig. 2), becoming quiet and less active, and the coat had a staring appearance.

After the lesions had ceased to show fluorescence, the guinea-pigs were maintained on their respective diets and were thereafter killed at varying intervals for physical and histological examination. A deficient animal and its corresponding control were examined together.

Post-mortem examinations were carried out on all animals. There were no gross macroscopic signs of disease.

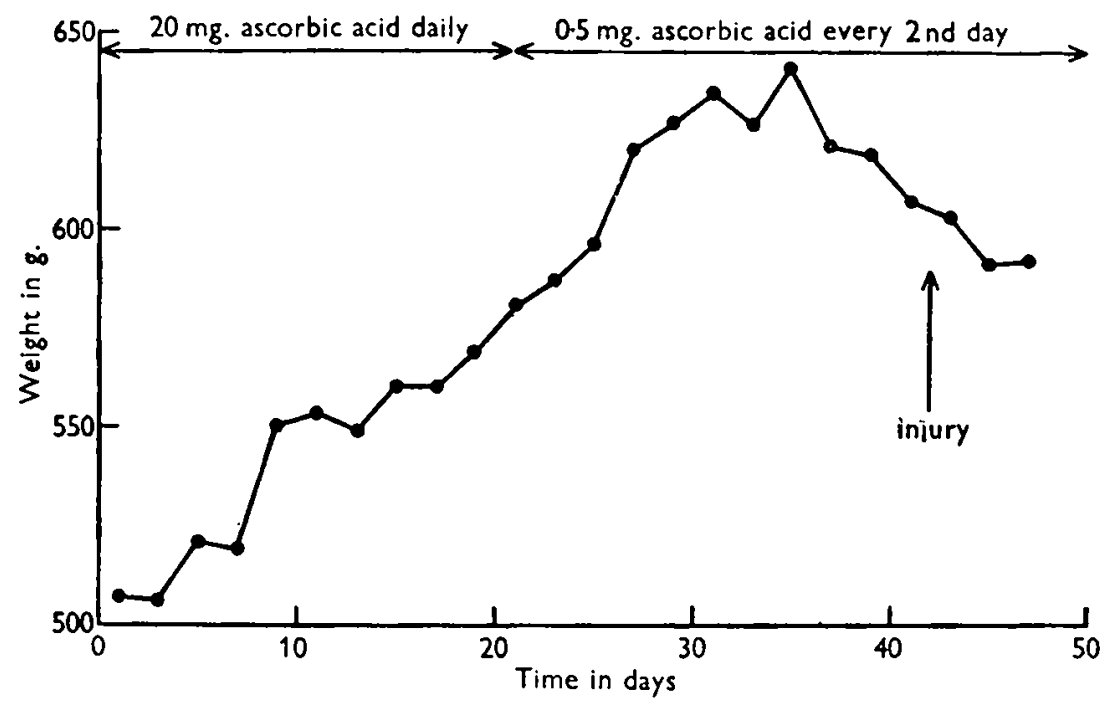

Fig. 2. Curve plotted from mean weights on alternate days of guinea-pigs in deficient group.

\section{Superficial corneal heat injuries}

Using the applicator heated to $180^{\circ}$, six control and eight deficient eyes were injured. The time of healing, as indicated by cessation of fluorescence, is shown below. The difference of $\mathrm{I}$ hr. between deficient and control animals is statistically not significant $(P>0 \cdot 9)$.

\begin{tabular}{|c|c|c|}
\hline $\begin{array}{l}\text { No. of } \\
\text { wounds }\end{array}$ & $\begin{array}{l}\text { Mean period for } \\
\text { healing (hr.)* }\end{array}$ & $\begin{array}{l}\text { Difference between control } \\
\text { and deficient animals }\end{array}$ \\
\hline $\begin{array}{l}6 \mathrm{C} \\
8 \mathrm{D}\end{array}$ & $\begin{array}{l}56 \cdot 0 \pm 7 \cdot 2 \\
55 \cdot 0 \pm 5 \cdot 5\end{array}$ & $\left\{\begin{array}{l}\text { Not significant } \\
P>0.9\end{array}\right.$ \\
\hline
\end{tabular}

An attempt was made to evaluate the mean fluorescence in both groups at injury and subsequently at $8 \mathrm{hr}$. intervals. A value $\circ$ was given when fluorescence was absent, a value 6 when fluorescence was most intense. 'The values attributed to the intensity of fluorescence from each lesion were summed for each group and divided by the number of eyes in the group. There was no difference between the behaviour of the two groups (Fig. 3). 
Even after cessation of fluorescence a faint corneal opacity persisted in four out of the fourteen eyes. Wolff (1947) states that a healed epithelial defect does not leave an opacity. Probably, therefore, we had injured to a slight degree Bowman's membrane,

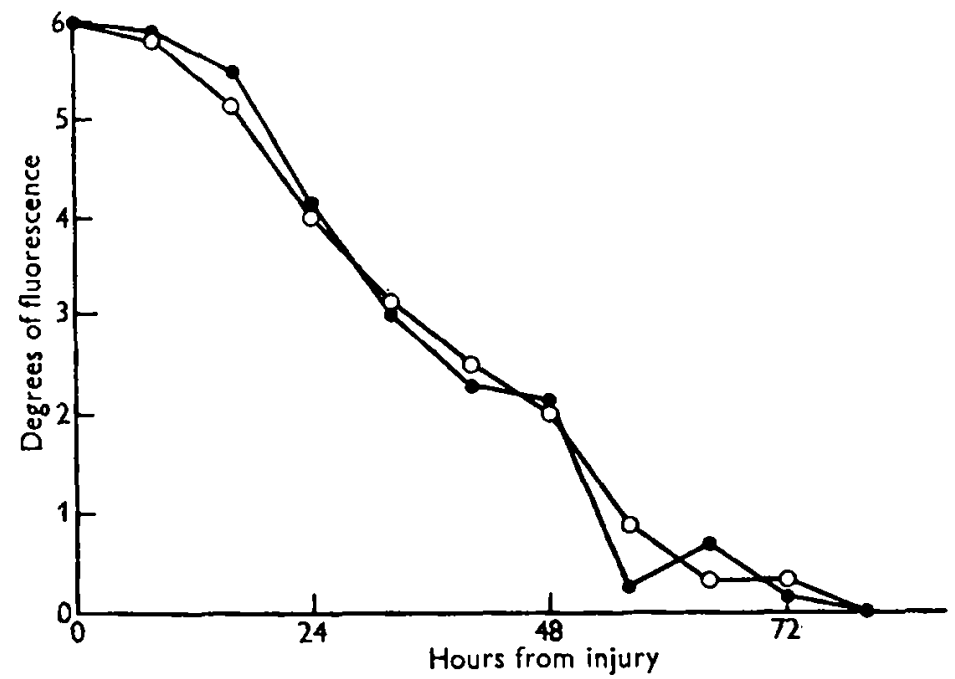

Fig. 3. Graph showing decline of mean intensity of fluorescence from corneal injuries made by applicator at $180^{\circ}$ (sce p. 34$)$. $O-O$, control animals; $-O$, deficient animals.

and possibly the substantia propria, when using the applicator at $180^{\circ}$. We repeated the experiment on ten control and eight deficient eyes using the applicator initially heated to $120^{\circ}$. The results were as follows:

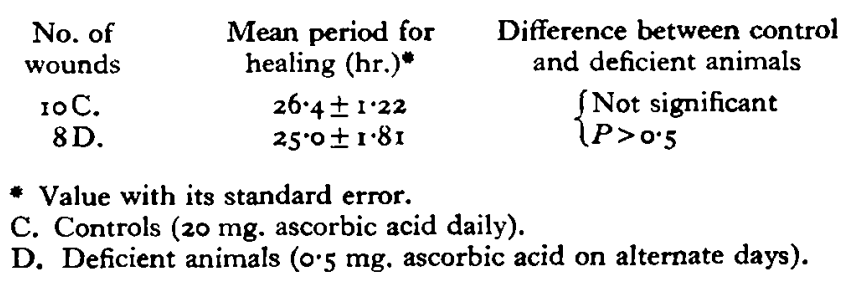

Once more the difference between the end-points as indicated by the disappearance of fluorescence was not significant $(P>0.5)$. In this series all opacities disappeared within $96 \mathrm{hr}$. from the time of injury.

It is interesting to note that the mean time for healing was markedly affected by the initial temperature of the applicator. 'The difference was highly significant $(P<0 \cdot 0 \mathrm{I})$ as the following figures show:

No. of wounds

14 at $180^{\circ}$ 18 at $120^{\circ}$
Mean period for healing (hr.)*

$55 \cdot 43 \pm 4 \cdot 232$

$25 \cdot 78 \pm \mathrm{I} \cdot 034$

* Value with its standard error. 


\section{Deep corneal heat injuries}

With this more severe type of injury there was a highly significant difference between the rate of healing in deficient and in control animals as indicated by the disappearance of fluorescence. The results are shown below:

\begin{tabular}{|c|c|c|}
\hline $\begin{array}{l}\text { No. of } \\
\text { wounds }\end{array}$ & $\begin{array}{l}\text { Mean period for } \\
\text { healing (hr.)* }\end{array}$ & $\begin{array}{l}\text { Difference between control } \\
\text { and deficient animals }\end{array}$ \\
\hline $\begin{array}{l}32 \mathrm{C} \\
32 \mathrm{D}\end{array}$ & $\begin{array}{r}94.00 \pm 6.02 \\
125.75 \pm 7.02\end{array}$ & $\left\{\begin{array}{l}\text { Highly significant } \\
P=0.00 \mathrm{r}\end{array}\right.$ \\
\hline
\end{tabular}

In guinea-pigs with deep corneal lesions opacities remained at the site of injury in all animals and persisted until they were killed.

During the healing process, assessment of the intensity of fluorescence, in the manner described above, gave the graph shown in Fig. 4. After the first few hours the lesions in the control animals gave, on the average, less intense fluorescence than the lesions in the deficient animals.

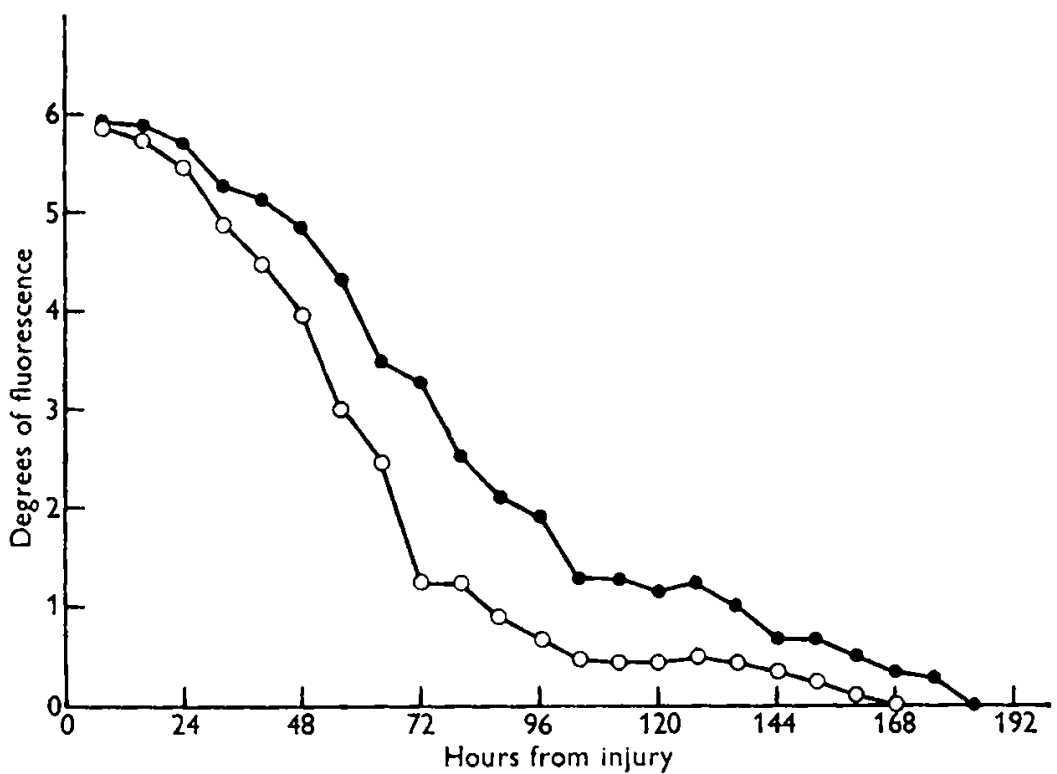

Fig. 4. Intensity of fluorescence following deep injuries to the cornea. $\mathrm{O}-\mathrm{O}$, control animals; - - deficient animals.

\section{The strength of the injured cornea}

In preliminary experiments, enucleation of eyes, previously injured by cautery, not infrequently led to perforation through the site of the lesion, although healing had so far progressed that all fluorescence had ceased. Obviously disappearance of fluorescence cannot be taken as an index of restoration of strength. Moreover, we received 
the impression that such rupture was more frequent among deficient animals than among controls.

We therefore designed the compression balance and subjected to stress twentyeight control eyes and twenty-six deficient eyes from the experiment with deep corneal lesions.

To estimate the degree of compression necessary to rupture the cornea through the site of the lesion, the excised eye was placed, cornea downwards, with the bar of the pivoted platform along the ' 3 to 9 o'clock' meridian of the eye (Fig. I, $X$ ). In this way considerable pressure was built up in the anterior chamber. If, however, the eye had not perforated by the time I roo g. had been applied to the scale pan, the eye tended to slip off the bar.

Twenty-one out of twenty-eight control eyes slipped off the bar without perforation. This is indicated by a $*$ sign after the highest value reached before slipping of the eye (Table 2). This value was perforce used for statistical analysis. In the deficient group twenty-one out of twenty-six eyes perforated. The $\chi^{2}$ test shows that such a result could only occur by chance once in a thousand $\left(\chi^{2}=x_{4} \cdot 64\right)$.

Table 2. Weights required to cause perforation of cornea

\begin{tabular}{|c|c|c|}
\hline \multirow{2}{*}{$\begin{array}{l}\text { Interval after } \\
\text { injury } \\
\text { (hr.) }\end{array}$} & \multicolumn{2}{|c|}{ Perforation pressure } \\
\hline & $\begin{array}{c}\text { Controls } \\
\text { (kg.) }\end{array}$ & $\begin{array}{l}\text { Deficient animals } \\
\text { (kg.) }\end{array}$ \\
\hline 218 & 0.8 & - \\
\hline 218 & 0.7 & - \\
\hline 242 & 0.8 & 0.5 \\
\hline 242 & 0.9 & 0.7 \\
\hline 264 & $x \cdot I^{*}$ & 0.7 \\
\hline 264 & $1 \cdot 7^{*}$ & 0.7 \\
\hline 288 & $1 \cdot 4$ & 0.9 \\
\hline 288 & $1 \cdot 2 *$ & 0.3 \\
\hline 288 & 0.3 & 0.8 \\
\hline 288 & 0.7 & 0.6 \\
\hline 314 & $1 \cdot 4^{*}$ & 0.9 \\
\hline 337 & 0.9 & 0.8 \\
\hline 337 & $1 \cdot 3 *$ & 0.9 \\
\hline 528 & $1 \cdot 2 *$ & 0.5 \\
\hline 528 & $1 \cdot 4 *$ & 0.9 \\
\hline 552 & $1 \cdot 2^{*}$ & 0.9 \\
\hline 552 & $1 \cdot 4 *$ & 0.9 \\
\hline 631 & $1 \cdot 5 *$ & $1 \cdot 4 *$ \\
\hline 631 & $1 \cdot 4 *$ & $I \cdot 2$ \\
\hline 672 & $1 \cdot 6^{*}$ & $1 \cdot 4$ \\
\hline 672 & 1.6 & $1 \cdot 5^{*}$ \\
\hline 672 & $1 \cdot 7^{*}$ & $1 \cdot 5$ \\
\hline 672 & $1 \cdot 4^{*}$ & 1.6 \\
\hline 696 & $1 \cdot 7 *$ & $x \cdot 6 *$ \\
\hline 770 & $1 \cdot 3^{*}$ & 1.4 \\
\hline 770 & $x \cdot 4 *$ & $1.5^{*}$ \\
\hline 2004 & $I \cdot 4^{*}$ & 1.4 \\
\hline 2004 & $1.6 *$ & $1 \cdot 6^{*}$ \\
\hline
\end{tabular}

- Indicates that the eye has slipped from the apparatus before perforation through the lesion had occurred.

Controls: $20 \mathrm{mg}$. ascorbic acid daily.

Deficient animals: $0.5 \mathrm{mg}$. ascorbic acid on alternate days. 
Inspection of Table 2 shows that, up to $55^{2} \mathrm{hr}$. following injury, the eyes from deficient animals perforated at a lower pressure than those from controls. Analysis of results up to $552 \mathrm{hr}$. is shown below. The difference between the two groups is statistically significant.

$\begin{array}{lcc}\begin{array}{c}\text { No. of } \\ \text { wounds }\end{array} & \begin{array}{c}\text { Mean weight for } \\ \text { perforation }(g .)^{*}\end{array} & \begin{array}{r}\text { Difference between control } \\ \text { and deficient animals }\end{array} \\ \text { 17 C. } & 1082 \pm 85 \cdot 9 & \left\{\begin{array}{l}\text { Significant } \\ P<0.01\end{array}\right. \\ \text { 15 D. } & 733 \pm 48 \cdot 5 & \\ \text { - Value with its standard error. } & \\ \text { C. Controls (20 mg. ascorbic acid daily). } \\ \text { D. Deficient animals (0.5 mg. ascorbic acid on alternate days). }\end{array}$

'The results from eyes injured more than $55^{2} \mathrm{hr}$. previously were not included in the analysis, since all eyes from the controls, and many from the deficient animals, slipped off the bar before perforation.

Table 2 shows also that in both groups, as healing progressed, a greater weight was required to cause perforation.

\section{The strength of the sclera}

After perforation of the cornea with loss of aqueous humour, the relatively large lens of the guinea-pig eye was displaced forward and prevented escape of vitreous humour. 'The bar was removed from platform $C$ and the eyes were placed, cornea upwards, to be compressed between the fixed support and the platform. Weights were added to the scale pan until the sclera ruptured. In these circumstances the eyes could not escape from the apparatus and the weight necessary for rupture of the sclera was obtained in every case.

'The mean weights required for deficient and for control animals are given below. 'There is no statistically significant difference between the two groups.

\begin{tabular}{|c|c|c|}
\hline $\begin{array}{l}\text { No. of } \\
\text { eyes }\end{array}$ & $\begin{array}{l}\text { Mean weight for } \\
\text { rupture (g.)* }\end{array}$ & $\begin{array}{l}\text { Difference between control } \\
\text { and deficient animals }\end{array}$ \\
\hline $\begin{array}{l}\text { I } 7 \mathrm{C} \\
3^{2} \mathrm{D}\end{array}$ & $\begin{array}{l}I 700 \pm 71 \cdot 2 \\
I 681 \pm 48 \cdot 5\end{array}$ & $\left\{\begin{array}{l}\text { Not significant } \\
P>0.8\end{array}\right.$ \\
\hline
\end{tabular}

\section{DISCUSSION}

'The significance of our findings depends to some extent on evaluation of the intensity of fluorescence after application of sodium-fluorescein solution. We accept, as do ophthalmologists, that disappearance of fluorescence indicates the restoration of an epithelial covering at the site of injury. We took care to standardize the strength $(2 \%)$ of the sodium-fluorescein solution instilled, the time of contact and the interval which elapsed before examination, since we had the suspicion that, in the early stages when the epithelial layers are few, the fluorescein with prolonged contact may penetrate to 
the regenerating tissues below and give a faint fluorescence. We found, too, that the presence of extraneous light interfered with the accurate assessment of the intensity of fluorescence.

\section{Superficial heat injuries of the cornea}

The repair of heat injuries, probably confined largely to the epithelial cells, is not influenced by ascorbic-acid deficiency, a finding in keeping with the results of Galloway et al. (1948-9), who inflicted mechanical wounds on the corneal epithelium. It may be that epithelial cells can divide and proliferate quite independently of a supply of ascorbic acid. On the other hand, corneal epithelium may be able to fill in a defect of moderate size without new formation of cells. If this be so, then there is no reason to expect a deficiency of ascorbic acid to delay healing of pure epithelial lesions.

\section{Deep heat injuries of the cornea}

Repair of injuries which penetrate Bowman's membrane and destroy the collagenous tissue of the substantia propria should be influenced by the presence or absence of ascorbic acid.

As judged by the time required for complete epithelialization, the healing of deep corneal wounds in scorbutic guinea-pigs is very definitely retarded. Yet we have just shown above that the process of simple replacement of epithelium is not impaired by a lack of ascorb: $c$ acid. We can only conclude that the slower rate of epithelialization in scorbutic guinea-pigs with deep wounds was due to the absence of a suitable substratum of collagenous tissue. This is in keeping with the hypothesis of Hartwell (r929) and with the suggestions of Galloway et al. (1948-9).

That there was delayed restoration of collagenous tissue in the deep corneal wounds of deficient guinea-pigs is borne out by the results of the experiments with the compression balance. There was, however, in the deficient guinea-pigs, no general weakening of the connective-tissue coat of the eye since the force required to rupture the sclera was similar in both deficient and control animals.

\section{SLMMARY}

I. Standard superficial and deep heat injuries were made on the corneas of guineapigs receiving either a wholly adequate $(20 \mathrm{mg}$. daily) or a deficient $(0.5 \mathrm{mg}$. every 2 nd day) intake of ascorbic acid.

2. The progress of repair was estimated both by instillation of a standard sodiumfluorescein solution and by subjection of the excised eyeballs to compression in a special balance.

3. The healing of superficial lesions, confined to the corneal epithelium, was not impaired by a deficiency of ascorbic acid.

4. On the other hand, deeper lesions, involving the substantia propria of the cornea, healed more slowly in the deficient guinea-pigs.

5. The healing lesions were structurally weaker in the scorbutic animals.

6. Thus, although restoration of corneal epithelium as such may be independent of an adequate supply of ascorbic acid, yet the rate of epithelialization of a wound of the 
cornea involving collagenous tissue does depend on the provision of a suitable fibrous tissue substratum and in turn on an adequate intake of ascorbic acid.

We are indebted to J. B. de V. Weir for help in design of the compression balance and for guidance in statistical analysis. We wish also to express our indebtedness to Roche Products Ltd. for the supply of ascorbic acid, and to the Rankin Medical Research Fund of the University of Glasgow for a grant to cover expenses.

\title{
REFERENCES
}

Arey, L. B. \& Covode, W. M. (1943). Anat. Rec. 86, 75.

Bourne, G. (1944). Lancet, 246, 688.

Buschke, W., Friedenwald, J. S. \& Fleischmann, W. (1943). Yohns Hopk. Hosp. Bull. 73, 143.

Campbell, F. W. \& Michaelson, I. C. (1949). Brit. Y. Ophthal. 33, 248.

Galloway, N. M., Garry, R. C. \& Hitchin, A. D. (1948-9). Brit. J. Nutrit. 2, 228.

Hartwell, S. W. (1929). Arch. Surg., Chicago, 19, 835.

Henkes, H. E. (1946). Ophthalmologica, I12, I13.

Jones, C. M., Bartlett, M. K., Ryan, A. E. \& Drummey, G. D. (1943). New Engl. F. Med. $229,642$.

Kellie, A. E. \& Zilva, S. S. (1939). Biochem. F. 33, 153.

Kuether, C. A., Telford, I. R. \& Roe, J. H. (1944). Y. Nutrit. $28,347$.

Mann, I. (1944). Brit. F. Ophthal. 28, 26.

Pirie, A. (1946). Biochem. F. 40, 96.

Schmid, A. F. \& Bürki, E. (1943). Ophthalmologica, ro5, 65.

Thomson, W. (1936). F. Hyg., Camb., 36, 24.

Wolbach, S. B. \& Howe, P. R. (1926). Arch. Path. Lab. Med. r, I.

Wolff, E. (1947). A Pathology of the Eye, and ed. Philadelphia: The Blakiston Company.

\section{Distribution of Radioactive Cobalt in the Rat}

\author{
By W. F. J. CUTHBERTSON, AUDREY A. FREE AND \\ DOREEN M. THORNTON \\ Research Division, Glaxo Laboratories Ltd., Greenford, Middlesex
}

(Received 2 Fanuary 1950)

The work to be reported here was carried out during an attempt to obtain vitamin $\mathbf{B}_{12}$ containing radioactive cobalt, ${ }^{60} \mathrm{Co}$. Previous experiments by Fantes, Page, Parker \& Smith (1949) have shown that it is not possible to label the vitamin $B_{12}$ molecule with radiocobalt by direct exchange with the cobalt of either radiocobalt chloride or hexamminocobaltic chloride, nor could exchange be demonstrated in the presence of liver tissue under the conditions employed. In the work to be reported here radioactive cobalt was administered under a variety of conditions to rats, in the hope that exchange reactions or biological synthesis would lead to the production of labelled vitamin $B_{12}$, and that this could then be isolated from the animals' livers.

\section{EXPERIMENTAL AND RESULTS}

General plan. Experiments of three types were carried out: ( 1 ) Short-term experiments were done to investigate the possibilities of biological exchange reactions, in which adult rats were maintained on a semi-synthetic diet low in cobalt and were given 